\title{
Łukasz Kalisz, 20-lecie Studium Teologii $w$ Biatymstoku, Wydawnictwo Uniwersyteckie Trans Humana, Białystok, ss. 163
}

Pogłębianie wiedzy religijnej, jak i samo jej tworzenie może przybierać różne postaci. Jedną z nich jest zapewne podjęcie studiów w kościelnym ośrodku kształcenia teologicznego, specjalnie do tego celu powołanego. Archidiecezja Białostocka, rozumiejąc tę potrzebę, stworzyła taki ośrodek powołując w 1977 roku Studium TeologicznoKatechetyczne, które w 1994 roku zostało afiliowane do Papieskiego Wydziału Teologicznego, Sekcji św. Jana Chrzciciela w Warszawie.

Łukasz Kalisz, jeden z absolwentów tej białostockiej uczelni, postanowił zgromadzić dostępne materiały i wydać drukiem o niej monografię. W ciagu 20 lat istnienia, Studium nie doczekało się obszernej publikacji, która opisywałaby zasady jego funkcjonowania. Słusznie zauważył ks. dr hab. Mieczysław Olszewski pisząc recenzję wydawniczą monografii, że opracowanie to ,wymagające skrupulatnego analitycznego studiowania materiałów źródłowych, zaangażowania w dotarcie do osób związanych wcześniej i obecnie ze Studium, zainteresowanie się losami absolwentów jest dziełem samym w sobie imponującym, a w sensie naukowo-poznawczym także dziełem wyjątkowym. Praca ta ukazuje także cząstkę historii nie tylko w sensie kościelnym, ale także społecznym dla miasta Białegostoku" (fragment z okładki). Podobnie ocenia tę książkę ks. bp dr hab. Henryk Ciereszko, pisząc w przedmowie: „Jest to opracowanie pionierskie, a zatem otwierające raczej teren badań niż całościowe i dogłębnie ujmujące zagadnienia, niemniej potrzebne i wartościowe dla historycznej i edukacyjnej pamięci naszej Archidiecezji Białostockiej i miasta Białegostoku” (s. 9).

Książka Łukasza Kalisza wpisuje się w dorobek historii wychowania, stanowiąc kompendium wiedzy na temat jednej z polskich uczelni teologicznych. W pracy wykorzystał on metodę monograficzną oraz analizę źródeł przechowywanych głównie w Archiwum Studium Teologii w Białymstoku. 
Publikacja jest podzielona na trzy rozdziały, zawiera także bibliografię, indeks osobowy oraz wykaz skrótów. W pierwszym rozdziale przedstawiona jest geneza powstania Studium Teologii w Białymstoku i okoliczności afiliacji do Sekcji św. Jana Chrzciciela Papieskiego Wydziału Teologicznego w Warszawie. W tym rozdziale zamieszczone jest także obszerne kalendarium obejmujące 20 lat istnienia Studium. W rozdziale drugim zostały zaprezentowane biogramy dyrekcji i pracowników naukowych Studium. W ostatnim rozdziale przedstawiono zasady rekrutacji i organizację studiów. Opisana została także działalność Rady Studenckiej, scholi i teatru. W tej części pracy zaprezentowano wykaz prac magisterskich powstałych w Studium Teologii, co pozwoli czytelnikom zorientować się w tematyce badawczej studentów i kierunkach badań ich promotorów. Dopełnieniem całości są materiały zdjęciowe, a także wspomnienia wybranych absolwentów Studium Teologii w Białymstoku oraz Oddziału „B” w Wilnie.

Autorowi opracowania, Łukaszowi Kaliszowi, należy pogratulować pomysłu udokumentowania i opisania historii Studium Teologii w Białymstoku i pięknego graficznie wydania monografii. We wstępie do książki autor napisał: „Kieruję ją do osób zajmujących się kształceniem teologicznym: do kapłanów, katechetów, dyrektorów i personelu placówek oświatowych i wychowawczych, a w szczególności do studentów i kadry naukowej uczelni teologicznych" (s. 12).

Myślę, że książkę tę mogą także z wielkim pożytkiem przeczytać osoby świeckie i w ten sposób zachęcić się do podjęcia nauki w Studium. Może to być swoistą przeciwwagą dla dość częstej ignorancji religijnej. Ta ignorancja nie tylko osłabia wiarę i zwiększa ryzyko grzechu, ale także zubaża kulturę i pogarsza jakość relacji międzyludzkich. Odbyte studia teologiczne stają się pomocą dla życia duchowego, a jednocześnie stanowią zachętę do kompetentnego szerzenia wiedzy religijnej w środowiskach rodzinnych, parafialnych i szkolnych. Pozostaje życzyć dalszego pomyślnego rozwoju tej placówki dydaktycznej oraz tego, aby pojawiły się kolejne prace poszerzające i dopełniające badania nad historią i dorobkiem naukowo-dydaktycznym naszej diecezjalnej teologicznej uczelni.

Ks. Adam Skreczko 